Disclosure of Interests: None declared

DOI: 10.1136/annrheumdis-2021-eular.1585

\section{AB0429 BELFAST TRUST EXPERIENCE OF IDIOPATHIC INFLAMMATORY MYOPATHIES}

S. Loughrey ${ }^{1}$, A. Herron ${ }^{1}$, M. Mchenry ${ }^{1}$, E. Ball' ${ }^{1}{ }^{1}$ Musgrave Park Hospital, Rheumatology, Belfast, United Kingdom

Background: The Idiopathic Inflammatory Myopathies (IIM) are a heterogeneous group of diseases where there is a growing field of knowledge and experience. Presentation is usually of onset of muscle weakness in combination with typical muscle biopsy findings and specific serum autoantibodies. There is a significant morbidity and mortality associated with IIM, due to its potential systemic nature, associated malignancy risk and side effects of immunosuppressive therapy1. There is no published guideline on management of IIM, with treatment limited to best practice experience.

Objectives: Review Belfast Trust experience of Adult IIM from 2009-2020

Methods: Review of Electronic Records of 18 patients diagnosed with IIM between 2009-2020

Results: 18 patients diagnosed with IIM. Mean age at diagnosis is 64 , with age range of 46-83. Mean duration of treatment is 4 years. 14 patients are in remission, 2 have active disease and 2 are deceased with cause of death unrelated to IIM.

Muscle Biopsy was performed in 17 patients. 11 patients biopsies were diagnostic and 6 were supportive. Of the patients with DM who did not have diagnostic muscle biopsies, all 3 had diagnostic skin biopsies. Of 6 patients with a negative

Table 1. Overview of diagnosis and treatment of patients with IIM. PM - Polymyositis DM - Dermatomyositis IBM - Inclusion Body Myositis IMNM Immune Mediated Necrotising Myositis EP - Extended Panel ILD Interstitial Lung Disease RA - Rheumatoid Arthritis RTx - Rituximab IVIG - Intravenous Immunoglobulin MTX - Methotrexate AZA -

Azathioprine MMF - Mycophenolate Mofetil SLZ - Sulphasalazine HLQ Hydroxychloroquine

\begin{tabular}{|c|c|c|c|c|c|c|c|c|c|}
\hline Diagnosis & $\begin{array}{l}\text { ANA/Extra } \\
\text { muscular }\end{array}$ & $\begin{array}{c}\text { Failed/ } \\
\text { Intolerance }\end{array}$ & RTxI & IVIGI & & IZAMMF & $\begin{array}{l}\text { Ciclos- } \\
\text { porin }\end{array}$ & $\begin{array}{l}\text { SLZI } \\
\text { HLQ }\end{array}$ & $\begin{array}{l}\text { Prednisolone } \\
\text { duration } \\
\text { (months) }\end{array}$ \\
\hline PM & Jo-1 Ro & AZA & & & & $\mathrm{x}$ & & & 18 \\
\hline PM & $\begin{array}{c}\text { Jo-1 } \\
\text { Myocarditis }\end{array}$ & AZA & $x$ & $x$ & & & $x$ & & 12 \\
\hline PM & $\begin{array}{c}\text { Negative. No } \\
\text { EP }\end{array}$ & $\begin{array}{c}\text { AZA/MMF/ } \\
\text { RTx }\end{array}$ & & & $x$ & & & & Maint. 3mg \\
\hline PM & $\begin{array}{c}\text { Negative. No } \\
\text { EP } \\
\text { ILD }\end{array}$ & & & & $x$ & & & & 22 \\
\hline PM & $\begin{array}{c}\text { Jo-1 } \\
\text { ILD, Mechanic } \\
\text { Hands }\end{array}$ & Mtx/MMF & $x$ & & & & & $x$ & Maint. $7 \mathrm{mg}$ \\
\hline PM & $\begin{array}{c}\text { Negative. No } \\
\text { EP }\end{array}$ & & & & & $\mathrm{x}$ & & & 36 \\
\hline PM & $\begin{array}{c}\text { Negative. No } \\
\text { EP }\end{array}$ & & $x$ & & & & & & $\begin{array}{c}18, \text { reducing } \\
\text { dose }\end{array}$ \\
\hline PM & $\begin{array}{c}\text { Negative. No } \\
\text { EP }\end{array}$ & & $x$ & & $\mathrm{x}$ & & & & Maint. 5mg \\
\hline PM & $\begin{array}{c}\text { Ro } \\
\text { ILD, } \\
\text { Dysphagia }\end{array}$ & & & $x$ & & & & & $\begin{array}{c}\text { 6, reducing } \\
\text { dose }\end{array}$ \\
\hline DM & $\begin{array}{l}\text { MDA5, Ro } \\
\text { Rash, ILD }\end{array}$ & AZA & $x$ & $x$ & & $X$ & & & 18 \\
\hline DM & $\begin{array}{l}\text { Mi2 } \\
\text { Rash }\end{array}$ & Mtx & $x$ & & & $X$ & & & 20 \\
\hline DM & $\begin{array}{l}\text { PM-SCL } \\
\text { Rash }\end{array}$ & & & & & & & & Deceased \\
\hline DM & $\begin{array}{l}\text { Ro52 } \\
\text { Sicca }\end{array}$ & & $x$ & & & & & & $\begin{array}{c}6, \text { reducing } \\
\text { dose }\end{array}$ \\
\hline DM & $\begin{array}{l}\text { MDA5, NXP2 } \\
\text { Rash }\end{array}$ & & $x$ & & & $x$ & & & Maint, $12.5 \mathrm{mg}$ \\
\hline $\begin{array}{l}\text { DM- } \\
\text { Amyopathic }\end{array}$ & $\begin{array}{l}\text { SAE } \\
\text { Rash }\end{array}$ & MTx & $x$ & $x$ & & $\mathrm{X}$ & & & Deceased \\
\hline IBM & Ro/La & & $\mathrm{x}$ & $x$ & & & & $x$ & $\begin{array}{c}\text { Unknown dura- } \\
\text { tion. Now } \\
\text { stopped }\end{array}$ \\
\hline IMNM & HMGCR & & & & $\mathrm{x}$ & & & & 12 \\
\hline IMNM & HMGCR & & $x$ & $x$ & $x$ & & & & $\begin{array}{c}18, \text { reducing } \\
\text { dose }\end{array}$ \\
\hline
\end{tabular}

ANA, 5 had a muscle biopsy performed (diagnostic in 4 patients and supportive in 1 patient.)

Conclusion: Extended myositis panels have only readily become available in the Belfast Trust in recent years. This has enhanced patients phenotypes and vigilance for extra-muscular complications. There is a recognised elevated risk of cancer in patients with IIM2. In our patients, with a mean disease duration of 4 years, none have developed malignancy. All of our patients had a tissue sample obtained, either muscle or skin. In the Belfast Trust, Rheumatologists perform muscle biopsies and all of the samples contributed to diagnosis. A limitation of diagnostic tests is restricted access to EMGs. We introduced a variety of DMARDs to limit exposure to steroids. $50 \%$ of our patients are in remission and off steroids. The only biologic we used was Rituximab. In contrast to other rheumatological conditions, there is no published protocol for administration of Rituximab in IIM. For patients with refractory disease, IVIG was used in the short term to allow for introduction of alternative immunosuppressants to maintain remission. This review highlights the complex nature of this group of diseases, and our experience with a variety of treatment options We have diagnosed and treated 18 patients, and although we have experience with the medications used to treat IMM further work is needed to establish evidence based treatment.

\section{REFERENCES:}

[1] Barsotti, Lundberg et al 'Current Treatment for Myositis' Curr Treatm Opt Rheumatol vol 4 (4) 2018 p299-315 2. Kang et al 'Temporal relationship between cancer and myositis identifies two distinctive subgroups of cancers: impact on cancer risk and survival in patients with myositis' Rheum vol 55 (9) 2016 p1631-1641

Disclosure of Interests: None declared

DOI: 10.1136/annrheumdis-2021-eular.1602

\section{AB0430 CONTRIBUTION OF SCLERODERMA/MYOSITIS- RELATED ANTIBODIES DETECTED BY IMMUNOBLOT TO THE DIAGNOSIS OF SYSTEMIC AUTOIMMUNE RHEUMATIC DISEASES IN 134 PATIENTS FROM A SINGLE REFERRAL CENTER}

D. Prieto-Peña ${ }^{1}$, B. Atienza-Mateo ${ }^{1}$, M. A. González-Gay ${ }^{1}$, R. Blanco ${ }^{1}$, M. Lopez-Hoyos ${ }^{2} .{ }^{1}$ Hospital Universitario Marques de Valdecilla, IDIVAL, Rheumatology, Santander, Spain; ${ }^{2}$ Hospital Universitario Marques de Valdecilla, IDIVAL, Immunology, Santander, Spain

Background: Immunoblot assays are increasingly used in clinical practice as part of the diagnostic armamentarium of systemic autoimmune rheumatic diseases (SARDs)

Objectives: To assess the contribution of an extended scleroderma/myositis-related antibodies $(\mathrm{Ab})$ determination by immunoblot to the diagnosis of patients with SARDs.

Methods: We reviewed all medical records of patients with positive scleroderma/ myositis-related $\mathrm{Ab}$ line blot determinations (Euroimmune AG, Lübeck, Germany) in our center from November 2017 to September 2020. These assays were requested due to high suspicion of SARDs in patients presenting with non-specific symptoms.

Results: 134 patients (37men/97women; mean age $59.6 \pm 14.8$ years) were positive for at least $1 \mathrm{Ab}, 25$ of them were positive for 2 Abs. Main clinica features at the time of immunoblot requests were: arthralgia/arthritis $(n=88)$, Raynaud's phenomenon $(n=59)$, rash $(n=27)$, sicca syndrome $(n=14.9 \%)$ myopathy $(n=18)$. During follow-up, 28 patients were diagnosed with undifferentiated connective tissue disease (UCTD), 26 scleroderma, 23 overlap myositis, 18 interstitial pneumonia with autoimmune features (IPAF), 8 other inflammatory diseases, 8 Sjögren's syndrome, 7 systemic lupus erythematosus, 5 dermatomyositis, 1 necrotizing myositis. In 10 patients the diagnosis of SARD was finally ruled out (Figure 1). Interstitial lung disease (ILD) was present in 50 patients, being particularly frequent in those with anti-PL12, anti-PL7 and anti-MDA5 Abs. Cancer was detected in $9(6.7 \%)$ patients, 6 of them were anti-Ro52 + (Table 1).

Conclusion: Immunoblot assays are of great help in the diagnosis of patients with high clinical suspicion of SARDs. While some Abs, such as anti-Ro52, anti-Ku and anti-PMScl75/100, remain to be nonspecific, other Abs including anti-PL12, anti-PL7 or anti-MDA5 are particularly helpful in detecting SARDs patients with associated ILD. 
REFERENCES:

Table 1.

\begin{tabular}{|c|c|c|c|c|c|c|c|c|c|c|c|c|c|c|c|}
\hline & $\begin{array}{l}M i-2 \\
(n=5)\end{array}$ & $\begin{array}{l}\text { PL-7 } \\
(n=6)\end{array}$ & $\begin{array}{l}\text { PL-12 } \\
(n=4)\end{array}$ & $\begin{array}{l}\text { Jo-1 } \\
(n=6)\end{array}$ & $\begin{array}{l}\text { MDA5 } \\
(n=1)\end{array}$ & $\begin{array}{c}\text { antiRo52 } \\
(n=57)\end{array}$ & $\begin{array}{l}\text { SRP } \\
(n=3)\end{array}$ & $\begin{array}{l}\text { Scl-70 } \\
(n=12)\end{array}$ & $\begin{array}{l}\text { CENP } \\
(n=14)\end{array}$ & $\begin{array}{l}\text { Th( } \\
n=2)\end{array}$ & $\begin{array}{c}\mathrm{Ku} \\
(\mathrm{n}=14)\end{array}$ & $\begin{array}{l}\text { Fibrilarina } \\
\qquad(\mathrm{n}=2)\end{array}$ & $\begin{array}{l}\text { PM-Scl75/100 } \\
(n=23)\end{array}$ & $\begin{array}{c}\text { NOR90 } \\
(n=8)\end{array}$ & $\begin{array}{c}\text { RNA pol } \\
(n=2)\end{array}$ \\
\hline ILD & 0 & $4(66.7)$ & $4(100)$ & $3(50)$ & $1(100)$ & 19 (33.3) & 0 & 7 (58.3) & $1(7.1)$ & 0 & $7(50)$ & $1(50)$ & $9(39.1)$ & $5(62.5)$ & 0 \\
\hline Cancer & $1(20)$ & 0 & 0 & 0 & 0 & $6(10.5)$ & 1 (33.3) & 0 & 0 & 0 & $1(7.1)$ & 0 & 0 & 0 & 0 \\
\hline
\end{tabular}

FIGURE 1

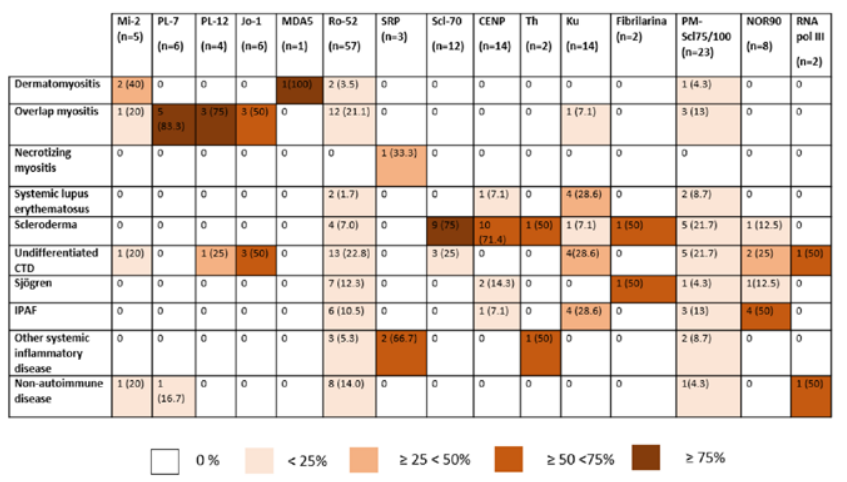

Disclosure of Interests: None declared

DOI: 10.1136/annrheumdis-2021-eular.1724

\section{AB0431 EXPLORING THE UTILITY OF THE AMERICAN COLLEGE OF RHEUMATOLOGY (ACR) CRISS IN PATIENTS WITH DIFFUSE CUTANEOUS SYSTEMIC SCLEROSIS}

F. Del Galdo ${ }^{1}$, O. Distler ${ }^{2}$, C. Denton ${ }^{3}$, Y. Allanore ${ }^{4}$, D. Wachtlin ${ }^{5}$, M. Alves ${ }^{6}$, D. Khanna ${ }^{7}{ }^{1}$ University of Leeds, Leeds Institute of Rheumatic and Musculoskeletal Medicine and NIHR Biomedical Research Centre, Leeds, United Kingdom; ${ }^{2}$ University Hospital Zurich, Department of Rheumatology, Zurich, Switzerland; ${ }^{3}$ University College London Division of Medicine, Centre for Rheumatology and Connective Tissue Diseases, London, United Kingdom; ${ }^{4}$ Descartes University, APHP, Cochin Hospital, Department of Rheumatology A, Paris, France; ${ }^{5}$ Boehringer Ingelheim Pharma GmbH \& Co. KG, Biostatistics + Data Sciences, Ingelheim, Germany; ${ }^{6}$ Boehringer Ingelheim International GmbH, TA Inflammation Med, Ingelheim, Germany; ${ }^{7}$ University of Michigan, Department of Medicine, Ann Arbor, United States of America

Background: The ACR Composite Response Index in diffuse cutaneous Systemic Sclerosis (CRISS) was developed to measure the probability of improvement in response to treatment in patients with early diffuse cutaneous SSC (dcSSc), accounting for new/worsening cardiopulmonary involvement and/or renal crisis, and changes in modified Rodnan skin score, forced vital capacity, health assessment questionnaire disability index, and patient's and physician's global impressions. In patients with SSc-ILD, treatment response may be reflected as slower progression, stabilisation or improvement.

Objectives: Using data from patients with dcSSc and ILD in the placebo group of the SENSCIS trial, we analysed the probability of improvement using the ACR CRISS score at week 52 . We also evaluated whether the CRISS numerator could provide information on the spectrum of responses in this patient population

Methods: The SENSCIS trial enrolled subjects with SSc-ILD with onset of first non-Raynaud symptom $\leq 7$ years before screening, FVC $\geq 40 \%$ predicted, and fibrotic ILD $\geq 10 \%$ extent on an HRCT scan. Subjects on prednisone $\leq 10 \mathrm{mg} /$ day (or equivalent) and/or stable therapy with mycophenolate or methotrexate were allowed to participate. Subjects were randomised to receive nintedanib or placebo. Subjects were not randomised by use of mycophenolate. In patients randomised to receive placebo who had dcSSc and/ or mRSS $>15$ at baseline, we analysed the ACR CRISS and its numerator at week 52 in subgroups by use of mycophenolate at baseline. Analyses were exploratory and descriptive.

Results: Of 117 analysed subjects in the placebo group who had dcSSc and/or mRSS $>15$ at baseline, 60 (51.3\%) were taking mycophenolate at baseline. Compared with patients not taking mycophenolate at baseline, those taking mycophenolate had a lower mean age (48.4 [SD 11.8] vs 53.1 [13.4] years), lower mean FVC \% predicted (68.8 [17.0] vs $73.0[14.6])$, and a greater proportion were female $(76.7 \%$ vs $71.9 \%)$; median time since first onset of non-Raynaud symptom was similar ( 3.9 vs 4.5 years, respectively) as was mean (SD) mRSS (16.5 [7.7] vs 15.9 [8.0], respectively). One patient (taking mycophenolate at baseline) had limited cutaneous SSc. At week 52, median (Q1, Q3) ACR CRISS score was $0.036(0.001,0.601)$ in subjects taking mycophenolate and $0.002(0.000$, 0.112 ) in subjects not taking mycophenolate at baseline, and mean (SD) ACR CRISS score was $0.28(0.37)$ in subjects taking mycophenolate and $0.16(0.31)$ in subjects not taking mycophenolate at baseline (Figure 1). In these groups, respectively, $25.0 \%$ and $14.0 \%$ of subjects had CRISS score $>0.6$ (considered improved) at week 52 . The CRISS numerator provided a broader distribution of response values, but was not informative in this patient population.

Conclusion: In exploratory analyses, among subjects with dcSSc and ILD who received placebo in the SENSCIS trial, the proportion considered improved at week 52 based on ACR CRISS score was numerically greater in patients taking than not taking mycophenolate at baseline. There remains a need for composite scores that provide better interpretation of the magnitude of response in patients with SSc.

\section{Figure. Box-and-whisker plot of CRISS score at week 52 in subjects with SSC-ILD with dcSSC and/or mRSS > 15 at baseline in the
placebo group of the SENSCIS trial by use of mycophenolate at baseline}

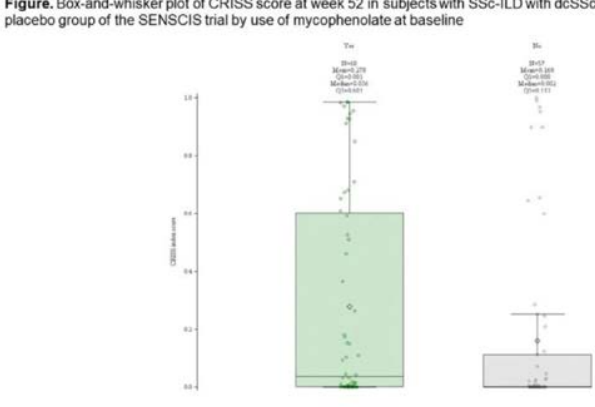

Acknowledgements: The SENSCIS trial was funded by Boehringer Ingelheim. Medical writing support was provided by FleishmanHillard Fishburn, London, UK. The authors meet criteria for authorship as recommended by the International Committee of Medical Journal Editors (ICMJE).

Disclosure of Interests: Francesco Del Galdo Speakers bureau: Actelion and AstraZeneca, Consultant of: Actelion, AstraZeneca, Boehringer Ingelheim, Capella BioScience, ChemomAb and Mitsubishi Tanabe Pharma, Grant/research support from: Capella BioScience, Kymab and Mitsubishi Tanabe Pharma, Oliver Distler Consultant of: AbbVie, Acceleron Pharma, Amgen, AnaMar, Arxx Therapeutics, Baecon Discovery, Bayer, Blade Therapeutics, Boehringer Ingelheim, ChemomAb, Corbus, CSL Behring, Galapagos NV, GlaxoSmithKline, Glenmark Pharmaceuticals, Horizon (Curzion) Pharmaceuticals, Inventiva, IQVIA, Italfarmaco, iQone Kymera Therapeutics, Lilly, Medac, Medscape, Merck Sharp \& Dohme, Mitsubishi Tanabe Pharma, Novartis, Pfizer, Roche, Sanofi, Serodapharm, Target Bioscience, Topadur Pharma and UCB, Grant/research support from: Kymera Therapeutics and Mitsubishi Tanabe Pharma, Christopher Denton Speakers bureau: Boehringer Ingelheim, Corbus, Janssen, and Mallinckrodt Pharmaceuticals, Consultant of: Acceleron Pharma, Arxx Therapeutics, Bayer, Boehringer Ingelheim, Corbus, CSL Behring, Galapagos NV, GlaxoSmithKline, Horizon Therapeutics, Janssen, Mallinckrodt Pharmaceuticals, Roche, Sanofi and UCB, Grant/research support from: Arxx Therapeutics, GlaxoSmithKline and Servier, Yannick Allanore Consultant of: Boehringer Ingelheim, Medsenic, Menarini and Sanofi, Grant/research support from: Alpine Pharmaceuticals, Daniel Wachtlin Employee of: Currently an employee of Boehringer Ingelheim, Margarida Alves Employee of: Currently an employee of Boehringer Ingelheim, Dinesh Khanna Shareholder of: Eicos Sciences, Inc. (less than 5\%), Consultant of: Acceleron Pharma, Actelion, AbbVie, Amgen, Bayer, Boehringer Ingelheim, CSL Behring, Corbus, Gilead Sciences, Galapagos NV, Genentech/Roche, GlaxoSmithKline, Horizon Therapeutics, Merck, Mitsubishi Tanabe Pharma, Sanofi-Aventis and United Therapeutics, Grant/research support from: Bayer, Bristol-Myers Squibb, Horizon Therapeutics, Immune Tolerance Network, National Institutes of Health and Pfizer, Employee of: Chief Medical OfficerCiviBioPharma/Eicos Sciences, Inc.

DOI: 10.1136/annrheumdis-2021-eular.1760 